\title{
Recognition of Beneckea natriegens (Payne et al.) Baumann et al. as a Member of the Genus Vibrio, as Previously Proposed by Webb and Payne
}

\author{
B. AUSTIN, A. ZACHARY, AND R. R. COLWELL \\ Department of Microbiology, University of Maryland, College Park, Maryland 20742
}

On the basis of a study of the biochemical, cultural, molecular genetic, morphological, nutritional, and physiological characters of the type strain (ATCC 14048) of Beneckea natriegens (Payne et al.) Baumann et al., we support the proposal by Webb and Payne that this organism is a member of the genus Vibrio.

A controversy has surrounded the taxonomic validity of the genus Beneckea since it was initially proposed by Campbell (2) to accommodate peritrichous cells of the family Achromobacteraceae which attack chitin. Baumann et al. (1) extended the description of Beneckea, although the relationship of their results to those of Campbell is unclear (2). Essentially, Beneckea was originally described as comprising gramnegative, peritrichous, facultatively anaerobic, straight rods of marine origin which are capable of degrading chitin and fermenting glucose with the production of acid but no gas (2). The revised description of Beneckea by Baumann et al. (1) includes gram-negative, fermentative, sodiumrequiring rods that are motile by means of single polar flagella. The overall deoxyribonucleic acid (DNA) base composition was given as 45 to 48 mol\% guanine plus cytosine $(G+C)$. However, Shewan and Véron (9) regard Beneckea as a genus incertae sedis and $B$. natriegens as a species of uncertain taxonomic position. Strains whose names bear the specific epithet "natriegens" acquired a checkered history for they have, at one time or another, been placed in the genera Pseudomonas (8), Beneckea (1), and Vibrio (10). On the basis of the phenotypic characters and DNA base composition of the type strain (ATCC 14048) of this species, we support the transfer of this organism to the genus Vibrio, as previously effected by Webb and Payne (10).

\section{MATERIALS AND METHODS}

Bacterial strain. A culture of the type strain of Beneckea natriegens obtained from the American Type Culture Collection, Rockville, Md., under the number 14048 (= strain 111 of P. Baumann) was used in this study. Bench cultures were maintained at room temperature, i.e., ca. $25^{\circ} \mathrm{C}$, on marine 2216 agar slants (Difco), with subculturing every 4 weeks.

Phenotypic characterization. The strain was examined through a wide range of tests currently used in extensive numerical taxonomy studies and as described by Colwell and Weibe (3). These tests included biochemical, cultural, nutritional, morphological, and physiological characters.

Determination of DNA base composition. The $\mathrm{G}+\mathrm{C}$ content of purified DNA, prepared by the method of Marmur (6), was determined from the thermal denaturation temperature $\left(T_{m}\right)(7)$ by using a Gilford 2400-S recording spectrophotometer at 260 $\mathrm{nm}$ programmed for temperature increases of $0.5^{\circ} / \mathrm{min}$. The $\mathrm{G}+\mathrm{C}$ content (in moles percent) was calculated from the $T_{m}$ by the equation of DeLey (5).

Electron microscopy. Cells were grown in a medium containing $0.25 \mathrm{M} \mathrm{NaCl}, 3.8 \mathrm{mM} \mathrm{KCl}, 0.018 \mathrm{M}$ $\mathrm{MgSO}_{4} \cdot 7 \mathrm{H}_{2} \mathrm{O}, 1 \%$ (wt/vol) nutrient broth (Difco), $0.5 \%$ (wt/vol) peptone (Difco), and $0.25 \%$ (wt/vol) yeast extract (Difco). After $3 \mathrm{~h}$ of incubation at $27^{\circ} \mathrm{C}$, with aeration, a $0.2-\mathrm{ml}$ sample of the cell suspension was negatively stained by using $2 \%$ (wt/vol) aqueous uranyl acetate. A second 0.2-ml sample was spread over an agar medium (as above, but gelled with $2 \%$ [wt/vol] agar). After $12 \mathrm{~h}$ of incubation at $27^{\circ} \mathrm{C}$, the cells were washed off the surface of the agar with a glutaraldehyde solution $(2 \%$ [vol/vol]; buffered with $0.2 \mathrm{M}$ sodium cacodylate at $\mathrm{pH} 7.4$ and containing the three salts mentioned above). The cells were subsequently negatively stained and examined by using a Hitachi HU11A transmission electron microscope.

\section{RESULTS AND DISCUSSION}

The phenotypic characters of $B$. natriegens ATCC 14048 determined in this study matched those of the description of strain 111 provided by Baumann and co-workers (1) insofar as the organism was a gram-negative, small, motile, facultatively anaerobic, rod-shaped bacterium that degraded starch, gelatin, and lipids but not sodium alginate or blood, grew on marine 2216 agar between 4 and $40^{\circ} \mathrm{C}$, was unable to decarboxylate arginine, but utilized a wide range of carbon compounds, including DL-alanine, cellobiose, ethanol, D-(-)-galactose, glycine, L(-)histidine, $\mathrm{D}-(-)$-mannitol, $\mathrm{L}-(-)$-ornithine $\mathrm{HCl}$, propanol, L-(-)-serine, sodium acetate, sodium butyrate, sodium caprylate, sodium citrate, sodium gluconate, sodium glutamate, sodium malate, sodium pelargonate, sodium propionate, so- 
dium valerate, sucrose, $\mathrm{L}-(-)$-threonine, and L$(-)$-tyrosine, as sole sources of carbon and energy. In contrast to the description of Beneckea by Campbell (2), peritrichous cells were not observed and chitin was not degraded.

Extensive transmission microscopy of $B . n a$ triegens ATCC 14048 grown in liquid media and on various solid surfaces, including agar, glass, polycarbonate filters, and plastic and metal surfaces, have consistently shown that only single, sheathed polar flagella (Fig. 1) or occasionally two (Fig. 2), or more rarely three, polar flagella are found. It is interesting that the $\mathrm{G}+\mathrm{C}$ ratio of $45.1 \mathrm{~mol} \%$ was lower than the value, $46.4 \mathrm{~mol} \%$, recorded by Baumann (1); our value agrees more closely with the $45.3 \mathrm{~mol} \%$ reported by Webb and Payne (10).

Since the characters of the type strain of $B$. natriegens do not match those of the original description of Beneckea as provided by Campbell (2), it appears unlikely that ATCC 14048 is a member of the genus Beneckea. Furthermore, we agree with Shewan and Véron (9) that the genus Beneckea should be considered a genus incertae sedis.
The taxonomic position of $B$. natriegens can be clarified by including this organism in the genus Vibrio. In particular, the organism possesses the general characteristics of the genus Vibrio, namely, it is a short, gram-negative, fermentative rod, is motile by means of one, and occasionally two or three, polar flagella, produces catalase and oxidase, and is susceptible to the vibriostatic agent $0 / 129$. Its DNA base composition of $45.1 \mathrm{~mol} \% \mathrm{G}+\mathrm{C}$ falls well within the range established for Vibrio spp., i.e., 40 to 50 mol\% $(4,9)$. Thus, the inclusion of $B$. natriegens in the genus Vibrio appears to be appropriate. Furthermore, the distinction between $B$. natriegens and other vibrios ( $V$. cholerae, $V$. parahaemolyticus, $V$. anguillarum, $V$. fischeri, and $V$. costicola), as measured by DNA base composition, arginine dihydrolase, growth at 5 and $37^{\circ} \mathrm{C}$, starch hydrolysis, and the utilization of sodium citrate as the sole carbon source for energy and growth, warrants the recognition of this organism as constituting a separate species. Thus, we recommend that Beneckea natriegens be regarded as a member of the genus Vibrio, as previously proposed by Webb and Payne (10).
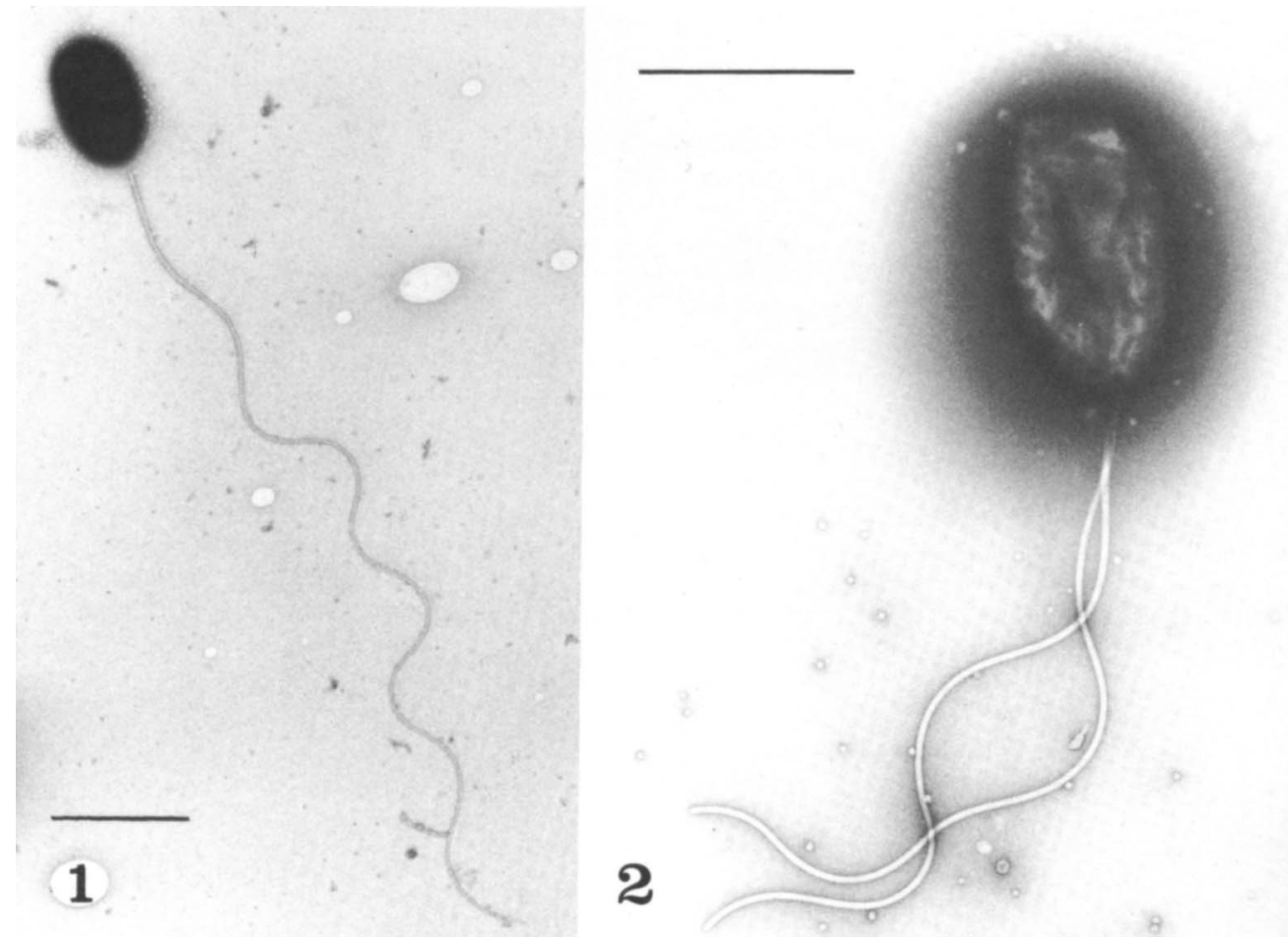

FIG. 1. ATCC 14048 cell, after 3 h of growth in liquid medium, stained with $2 \%$ (wt/vol) uranyl acetate. Bar equals $1 \mu \mathrm{m}$.

FIG. 2. Negatively stained cell of ATCC 14048 showing two polar flagella. The culture was grown for $12 \mathrm{~h}$ on a solid medium. Bar equals $1 \mu \mathrm{m}$. 


\section{ACKNOWLEDGMENTS}

We are grateful to Sue Garges for determining the deoxyribonucleic acid base composition.

This work was supported by National Science Foundation grant 72-02227 A04 and National Aeronautics and Space Administration grant NAS-8-32148.

\section{REPRINT REQUESTS}

Address reprint requests to: Dr. R. R. Colwell, Department of Microbiology, The University of Maryland, College Park, MD 20742.

\section{LITERATURE CITED}

1. Baumann, P., L. Baumann, and M. Mandel. 1971. Taxonomy of marine bacteria: the genus Beneckea. J. Bacteriol. 107:268-294.

2. Campbell, L. L. 1957. Genus V. Beneckea Campbell gen. nov., p. 328-332. In R. S. Breed, E. G. D. Murray, and N. R. Smith (ed.), Bergey's manual of determinative bacteriology, 7th ed. The Williams \& Wilkins Co., Baltimore.

3. Colwell, R. R., and W. J. Weibe. 1970. "Core" characteristics for use in classifying aerobic, heterotrophic bacteria by numerical taxonomy. Bull. Georgia Acad.
Sci. 28:165-185

4. Cowan, S. T. 1974. Cowan and Steel's manual for the identification of medical bacteria. Cambridge University Press, Cambridge.

5. De Ley, J. 1970. Re-examination of the association between melting point, buoyant density and chemical base composition of deoxyribonucleic acid. J. Bacteriol. 101:738-754.

6. Marmur, J. 1961. A procedure for the isolation of deoxyribonucleic acid from microorganisms. J. Mol. Biol. 3:208-218.

7. Marmur, J., and P. Doty. 1962. Determination of the base composition of deoxyribonucleic acid from its thermal denaturation temperature. J. Mol. Biol. 5:109-118.

8. Payne, W. J., R. G. Eagon, and A. K. Williams. 1961. Some observations on the physiology of Pseudomonas natriegens nov. spec. Antonie van Leeuwenhoek J. Microbiol. Serol. 27:121-128.

9. Shewan, J. M., and M. Véron. 1974. Genus 1. Vibrio Pacini 1894, p. 340-345. In R. E. Buchanan and N. E. Gibbons (ed.), Bergey's manual of determinative bacteriology, 8th ed. The Williams \& Wilkins Co., Baltimore.

10. Webb, C. D., and Payne, W. J. 1971. Influence of $\mathrm{Na}^{+}$ on synthesis of macromolecules by a marine bacterium. Appl. Microbiol. 21:1080-1088. 